\title{
FINANCIAL ANALYSIS AND OPTIMIZATION OF FLOATING MEDIA TECHNIQUES OF PEGAGAN RICE CULTIVATION IN SOUTH SUMATRA, INDONESIA
}

\author{
Bidarti Agustina*, Sriati, Purbiyanti Erni \\ Department of Agricultural Social-Economics, University of Sriwijaya, Indonesia \\ *E-mail: agustinabidarti@unsri.ac.id
}

\begin{abstract}
This study aims to introduce the cultivation of floating media rice crops, conduct a financial analysis of floating media techniques on pegagan rice, publicize the planting of local rice pegagan twice a year. Study methods in the form of observation, questioner, mentoring, and development. the study was conducted for 4 months. Based on the study of farmers has improved knowledge and skills applying floating media techniques of pegagan rice cultivation. Financial analysis of raft making for floating media techniques of pegagan rice cultivation per season amounted to $2.544,54 \mathrm{USD} / \mathrm{Ha} / \mathrm{season}$. If the receipt is above the figure, it can be said that farmers will experience profits.
\end{abstract}

\section{KEY WORDS}

Floating media, rice paddies, pegagan rice, financial analysis, farmer group.

During the Covid-19 pandemic, rice production must continue to be considered and improved, thus ensuring food needs in South Sumatra. (Bidarti, 2020) At the end of the year, South Sumatra, it will usually be faced with a climate change situation accompanied by increasing and high rainfall. This condition will cause rice growers in south Sumatra, including Ogan Ilir Regency, to be particularly vulnerable to the risk of flooding on rice fields. The effects of climate change are quite pronounced in Ogan Ilir Regency, based on several studies on rice farming patterns there are very susceptible to water inundating that can lead to crop failure of farmers (Hasmeda et al., 2017).

In 2019, according to the Bidarti et al. (2019) study, in Ogan Ilir County there were 20 rainy days with only 10 days without rain. The number of rainy days, resulting in flooding on rice fields in some sub-districts in Ogan Ilir Regency, including in Segayam Village. Interestingly, flooding in rice fields tends to have a negative impact both socially and economically because it is vulnerable to food insecurity. The results of Saleh et al. (2019) there is a phenomenon of increased crop failure due to extreme climate events, the problem of rising tides. Therefore, it is necessary to strategize and optimize rice planting in Ogan Ilir. One of the strong rice against puddles is local rice, Pegagan rice.

Based on the studies of Hasmeda et al. (2017), Kodir et al. (2018), which conducted morphological and physiological studies of some local rice varieties of lebak swamps, concluded that pegagan rice varieties have better characteristics and properties than other local rice varieties. This variety can survive in a submerged state for one week in the vegetative phase. Rice planting to increase food production in South Sumatra must adopt various new technologies, one of which is the floating media technique. Floating media technology is still very new and not widely known, so to change the mindset of farmers to shift the way conventional farming to floating rice technology takes time (Adinata, 2012; Saleh et al, 2019).

Technically, the floating rice cultivation media technique is a rice cultivation technique that uses rafts as planting media. The raft serves as a restraint so that the plant does not collapse when hit by the wind and does not sink in flooded land. The rafts used are made of paralon and styrofoam braid for easy floating. (Adinata, 2012) Rice used in floating media techniques is Pegagan rice. The practice of floating farming has been done since time immemorial in Bangladesh (Assaduzzaman, 2014) and the Intha community in Myanmar. (Tan, 2017). 
Financial analysis and potential development of floating rice have been reviewed by Suryatiyah (2016), which shows that financially the development of floating rice is very profitable as well as one of the solutions in addressing climate change. Based on the above studies, plus Bidarti et al. (2018) studies, it can be said that the lack of knowledge in the community of the study site is caused by discontentment, especially about floating rice cultivation technology that is considered expensive and troublesome.

Based on such studies and situations, this study introduces the optimization of the introduction of floating media cultivation techniques for pegagan rice, as well as conducting its financial analysis. This floating media technique is performed on the cultivation of pegagan rice as a local seedling Ogan llir that is resistant to puddles during the tide.

\section{MATERIALS AND METHODS OF RESEARCH}

The methods used are observation, mentoring, and development. The sample involved 150 people from several 30 members of a farming group in Segayam Village, North Indralaya District, Ogan Ilir Regency, South Sumatra, Indonesia. Observations equipped with recording and questioner are carried out during 2 assessments, pre-test and post-test. Financial analysis is carried out for the materials and tools used. Analysis tools are a descriptive approach to measuring farmers' knowledge levels and skills with a scoring method called Work Achievement Score (NPK). The formula of Work Achievement Value (NPK) used is: $\mathrm{NPK}=($ Total NEM $) / 80 \times 100$.

Furthermore, for financial analysis using the method of the feasibility of agricultural activities that according to Suryatiyah (2016) uses a formula of $\mathrm{R} / \mathrm{C}$ ratio value greater than one, meaning any additional costs incurred will result in additional acceptance greater than additional costs or simply profitable farming activities.

\section{RESULTS AND DISCUSSION}

Farmer's knowledge in floating media techniques of pegagan rice cultivation in Segayam, South Sumatra is measured from a knowledge of floating media tools, floating media materials, pegagan rice seed selection, pegagan rice seed planting, fertilization, weeding, pest and disease control, harvesting and post-harvest floating rice. Before mentoring, the measurement of the knowledge component of farmers with a pre-test. Furthermore, after the assistance is reassessed, post-test. The results of the assessment of knowledge before and after mentoring can be seen in Figure 1.

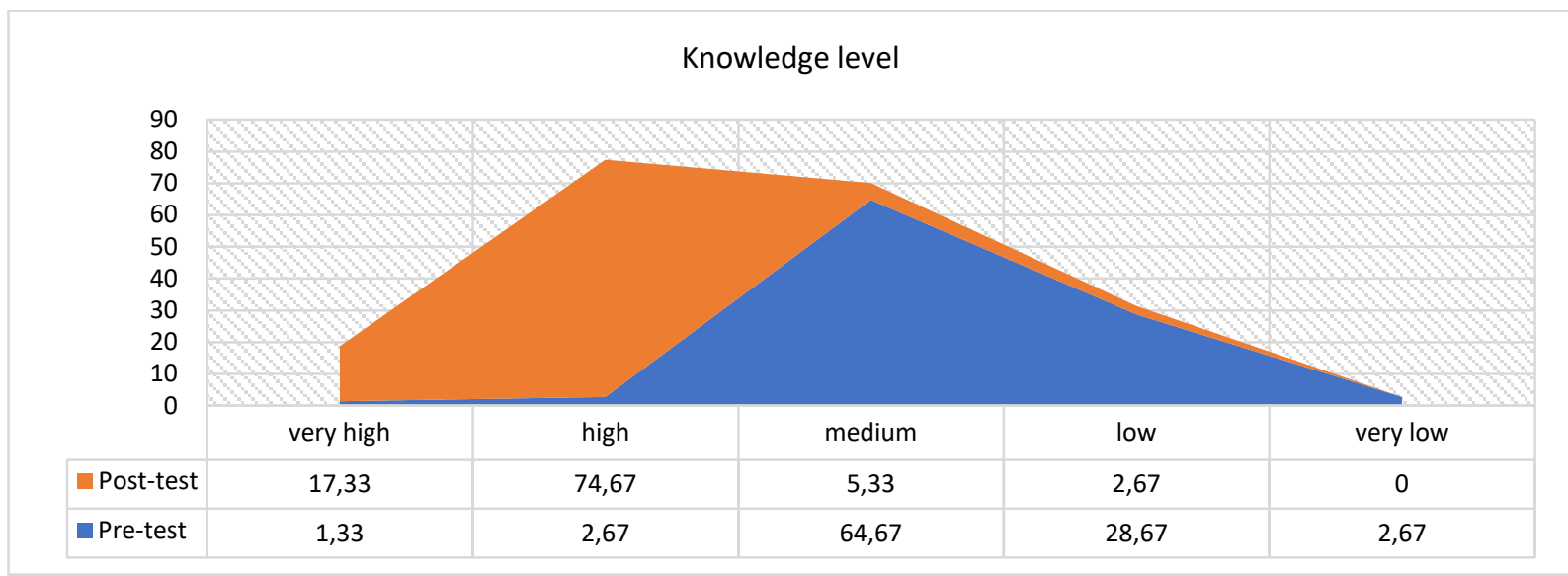

Figure 1 - Level of knowledge of farmers in floating media techniques of pegagan rice cultivation

Based on Figure 1, there is a significant increase in farmer knowledge in applying floating media techniques of pegagan rice cultivation in Segayam Village, Ogan Ilir Regency. Before the enactment of the farmer's rate of entry was at moderate criteria of $84.67 \%$, and 
experienced an increase in the high criteria with a value of $91.33 \%$ after enactment. Based on questioner data, factors that influence knowledge in general, such as education, sociocultural, economic, environmental, experience, and age.

Furthermore, it is also measured the skill level of farmers in floating media techniques of pegagan rice cultivation in Segayam, South Sumatra. Measurements are made before and after enforcement. The results of the assessment of the skills of applying floating media techniques of pegagan rice cultivation in Segayam Village, Ogan llir Regency can be seen in Figure 2.

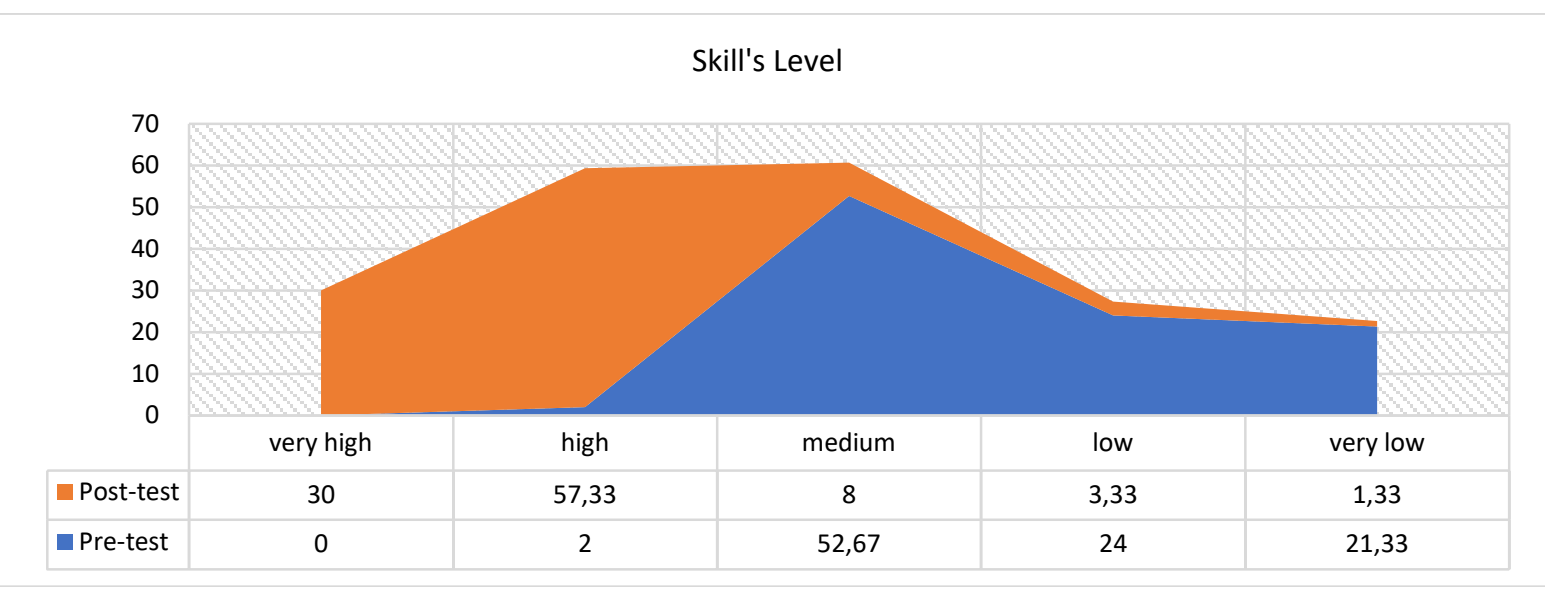

Figure 2 - Level of skill's of farmers in floating media techniques of pegagan rice cultivation

The skill level of farmers in applying floating media techniques of pegagan rice cultivation in Segayam Village, Ogan llir Regency has increased. Based on graph 2, before enactment is low criteria of $73.00 \%$. It increased after enactment to a high criterion with a score of $\mathbf{8 7 . 3 3 \%}$. Based on quesioner, factors that affect skills include experience and age.

For financial analysis conducted during the assistance in the study sample. The implementation of assistance in the manufacture of floating media techniques of pegagan rice cultivation in Segayam Village, Ogan Ilir Regency is still limited to trials, to date, no farmers have independently implemented the technology. This is because it is still a trial phase to obtain a financially profitable technology package for pegagan floating rice farming. Data on the cost of making rafts for floating media techniques of pegagan rice cultivation in Segayam Village, Ogan Ilir Regency made of paralon is presented in the following table.

Table 1 - Cost of making a raft with paralon material (raft size $2 \mathrm{~m} \times 4 \mathrm{~m}$ )

\begin{tabular}{llllll}
\hline No & Material Type & $\begin{array}{l}\text { Number } \\
\text { (unit) }\end{array}$ & Unit & $\begin{array}{l}\text { Price } \\
\text { (USD/unit) }\end{array}$ & Total Price (USD) \\
\hline 1 & Great paralon & 5 & stick rod & 8,83 & 41,65 \\
2 & Small paralon & 3 & stick rod & 4,24 & 12,72 \\
3 & Large paralon hubp & 8 & Pieces & 0,53 & 4,24 \\
4 & Styrofoam & 10 & Metres & 0,18 & 1,80 \\
5 & Trawler nets & 4 & Metres & 0,36 & 1,44 \\
6 & 5 mm measuring rope & 0.5 & Roll & 8,25 & 4,12 \\
7 & Labor costs & 0.5 & working hours & 5,33 & 2,65 \\
\hline Total cost & & & 68,62 \\
\hline
\end{tabular}

Based on the table above it is known that the manufacture of rafts for floating media techniques of pegagan rice cultivation in Segayam Village, Ogan llir Regency when using paralon materials costs 68,62 USD/raft. Paralon material can be used for longer which is up to a minimum of 10 years.

Using paralon material costs per hectare up to $850 \times 68,62$ USD $=58.327,01$ USD assuming it can be used for up to 15 years and there is a cost-efficiency if making a lot about 30 percent, then the cost per season is $2.544,54 \mathrm{USD} / \mathrm{Ha} /$ season. If the receipt is above the figure, it can be said that farmers will experience profits. 


\section{CONCLUSION}

The study of applying floating media techniques of pegagan rice cultivation, such as in South Sumatra is a very feasible mass application. First, the farmers there continue to experience increased knowledge and skills in making floating rice media techniques. Before the implementation of the knowledge level farmers were only on moderate criteria, at $84.67 \%$. Furthermore, after enforcement increased on high criteria, by $91.33 \%$. Thus for the skill level, before enactment is only at a low criterion, of $73.00 \%$. It increased to a high criterion, by $87.33 \%$ after enactment.

Based on the financial analysis of raft making for floating media techniques of pegagan rice cultivation in Segayam Village, Ogan Ilir Regency with paralon material costs 68,62 USD/raft. Assuming it can be used for up to 15 years and there is a cost-efficiency if it makes a lot about 30 percent, then the cost per season is $2.544,54 \mathrm{USD} / \mathrm{Ha} /$ season. If the receipt is above the figure, it can be said that farmers will experience profits.

\section{AKCNOWLEDGMENTS}

This article is part of University of Sriwijaya PKM Grant in 2020.

\section{REFERENCES}

1. Assaduzzaman, M. (2014). Floating Agriculture in the Flood-prone or Submerged Areas in Bangladesh (Southern Regions of Bangladesh). Bangladesh Resource Centre for Indigenous Knowledge (BARCIK). Dhaka, Bangladesh.

2. Adinata, K. (2012). Petunjuk Teknis Padi Apung. IPPHTI, Cilacap.

3. Bidarti, A. (2020). Survive of the Indonesian Farmers in During the Covid-19 Pandemic: The Case of the South Sumatra. Presented at ICoSI 2020 Conference, 13-14 Augustus 2020, Universitas Muhammadiyah Yogyakarta, Indonesia.

4. Bidarti, A., Husin, L., and Yulius. (2019). Structure of Rice Demand and Consumer Lexicographic Preferences in Indonesia. Russian Journal of Agricultural and SocioEconomic Sciences (RJOAS), 12(96): 27-32.

5. Hamzah, M., Bidarti, A., Anggraini, E., and Antoni, M. (2019). Comparisons of Farmers' Income and Capital Creation base on Different Sources of Rice Farming Financing in South Sumatra, Indonesia. Russian Journal of Agricultural and Socio-Economic Sciences (RJOAS), 1(85): 134-141

6. Bidarti, A., and Hartono, S. (2016). Suppliers Structure And Performance Evaluation Supplier Network Stagein The Supply Chain Management Of Rice In South Sumatra. Advances In Global Business Research, 13(1): 2536-2549

7. Hasmeda, M., Suwignyo, R.A., Wibisono, I., and Hamidson, H. (2017). Analysis of Submergence Tolerant Gene (Sub-1) on BC2F1 Population, Backcross of Selected Swamp Rice Genotype Using Molecular Marker. Journal of Advanced Agricultural Technologies, 4(4): 350-353

8. Kodir, K.A., Juwita, Y., and Sasmita, .P. (2018). Karakterisasi Padi Lokal, Pegagan (Siputih) pada Agroekosistem Rawa Lebak Sumatra Selatan. Bulettin Plasma Nutfah, 24(2):77-82.

9. Saleh, E., M. Umar Harun, M.U., Priatna, S.J., and Sanjaya, R. (2019). Adaptasi Pola Genangan Air Rawa Lebak dengan Budidaya Tanaman Padi Mengambang di Desa Pelabuhan Dalam, Kabupaten Ogan Ilir.Jurnal Pengabdian Sriwijaya, 7(1), 703-709

10. Suratiyah, K. (2016). IImu Usahatani: Biaya and Pendapatan dalam Usahatani. (Jakarta: Penebar Swadaya)

11. Tan, M.M. (2017). Community Activities Contribution To Water Environment Conservation Of Inle Lake. Union Of Myanmar Ministry Of Agriculture And Irrigation, Irrigation Department. Myanmar. 